\title{
Migratory Patterns of Sympathetic Ganglioblasts and Other Neural Crest Derivatives in Chick Embryos
}

\author{
Joseph W. Yip \\ Department of Physiology, School of Medicine, University of Pittsburgh, Pittsburgh, Pennsylvania 15261
}

\begin{abstract}
While it is well established that neural crest cells migrate to give rise to a variety of cell types and tissues, the migratory patterns among individual neural crest derivatives have not been fully worked out. Such knowledge is important not only in relation to the mechanisms of neural crest migration and differentiation, but also in understanding the ontogeny of the PNS. Of special interest in the latter regard is the origin of sympathetic ganglion cells and their innervation, since studies on ganglion cell innervation have suggested that the matching between pre- and postganglionic neurons might be based on their early positions along the neuraxis (see preceding paper). In the present study, I have used the quail-chick transplantation technique to examine the migratory patterns of the precursors of sympathetic ganglion cells, dorsal root ganglion cells, and melanocytes that originate from 1 or 2 segments of the trunk neural crest. My results indicate that precursors of sympathetic ganglion cells, on average, migrate 2 segments rostrally and 3 segments caudally. Thus, individual sympathetic ganglia comprise neurons that originate from up to 6 segments of the neuraxis. Precursors of melanocytes also migrate along the rostrocaudal axis, but to an even greater extent than sympathetic ganglioblasts. In contrast, precursors of dorsal root ganglion cells do not migrate at all along the rostrocaudal axis (although they migrate along a ventromedial pathway to give rise to the dorsal root ganglia of the same segmental level).

The number of neural crest segments contributing to each sympathetic ganglion is approximately equal to the number of spinal cord segments contributing to its innervation. This finding is consistent with the idea that the segmental innervation of particular sympathetic ganglia is related to the segmental origin of their constituent cells.
\end{abstract}

The neural crest is a transient structure that overlies the neural tube of the vertebrate embryo and gives rise to a variety of cell types and tissues. Among the derivatives of the neural crest are neurons of sensory and autonomic ganglia, glial cells, melanocytes, cells of the adrenal medulla, and many craniofacial structures (for review, see LeDouarin, 1982). At the level of the trunk, neural crest cells migrate in 2 streams, one ventromedially adjacent to the lateral wall of the neural tube and the other dorsolaterally between the somites and the ectoderm. Neural crest cells that migrate ventromedially give rise to the sympathetic chain ganglia and plexus, dorsal root ganglia, and the adrenal medulla; the dorsolaterally migrating cells enter the dermis to

\footnotetext{
Received Dec. 30, 1985; revised May 6, 1986; accepted July 8, 1986.

This work was supported by BNS82-10028 and by a Basil O'Connor Starter Research Grant from the March of Dimes Birth Defects Foundation. I thank Dale Purves, Jeff Lichtman, Dan Simons, and Wes Thompson for critical comments on the manuscript. $P$. Rice for technical assistance, Sandy Fstocsin for typing, and Bill Brent for illustrations.

Correspondence should be addressed to Joseph W. Yip at the above address. Copynght @ 1986 Society for Neuroscience $0270-6474 / 86 / 123465-09 \$ 02.00 / 0$
}

become melanocytes (Thiery et al., 1982; Vincent and Thiery, 1984; Weston, 1963). How neural crest cells originating from the same region end up in different locations and differentiate into different cell types is not fully understood. Although many studies have examined the overall pathways of neural crest migration (Duband and Thiery, 1982; LeDouarin and Teillet, 1974; Newgreen and Thiery, 1980; Noden, 1975; Teillet, 1971; Tosney, 1978), none has examined the pattern of migration of cells derived from a very small region of the neural crest. This issue becomes important in a consideration of the innervation of sympathetic ganglia; recent studies have demonstrated that ganglion cell innervation by preganglionic neurons is selective and have suggested that selective synaptogenesis in this system is based on surface labels that are acquired as a result of the segmental origins of pre- and postganglionic neurons along the neuraxis (Lichtman et al., 1979; Purves et al., 1981; Rubin and Purves, 1980). In the present study, I have examined the pattern of migration of sympathetic ganglioblasts, sensory ganglioblasts, and pigment cells that originate from 1-2 segments of the trunk neural crest in the chick embryo. Several questions concerning neural crest migration were examined. (1) Are neural crest cells of the trunk capable of substantial rostrocaudal migration? (2) Do precursors of different neural crest derivatives have different propensities to migrate in the rostrocaudal axis? (3) What is the segmental origin of the neurons making up the cervical and thoracic sympathetic chain ganglia? These questions were addressed by following the migration of neural crest cells derived from quail neural primordia transplanted homotopically into chick hosts (LeDouarin, 1969, 1971, 1973).

\section{Materials and Methods}

Transplantation of neural primordium from a quail donor into a chick host

Quail neural crest cells, identified by their condensed heterochromatin, were used as markers for identifying the migratory pattern of sympathetic and dorsal root ganglion cell precursors in the chick (Fig. 1). Using a rotary sander, windows were made in the shell of both quail and chick embryos. One or two segments of neural primordium consisting of neural tube and the overlying neural crest were removed by tungsten needles from lower cervical or upper thoracic segments of a quail donor at stages $11-15\left(2-2 \frac{1}{2}\right.$ d). The specific level of the neural tube was determined by counting somites after lightly staining the embryo with a $0.1 \%$ neutral red solution (Levi-Montalcini, 1950). All donor tissues were obtained from regions of the last 6 somites in stage 14-15 embryos and from the unsegmented region in the vicinity of the last somite in stage 11-13 embryos. The donor tissue was transplanted into a chick host of the same stage from which the corresponding segments had been removed (Fig. $2 A$ ). The window in the shell of the chick host was sealed with a coverslip and paraffin, and returned to a forced-draft incubator at $37^{\circ} \mathrm{C}$ and $70 \%$ relative humidity. Host embryos were sacrificed at stages 33-38 (71/2-12 d) (Hamburger and Hamilton, 1951). Only those embryos that appeared morphologically normal were used (Fig. $2 B$; see also Fig. 8). 

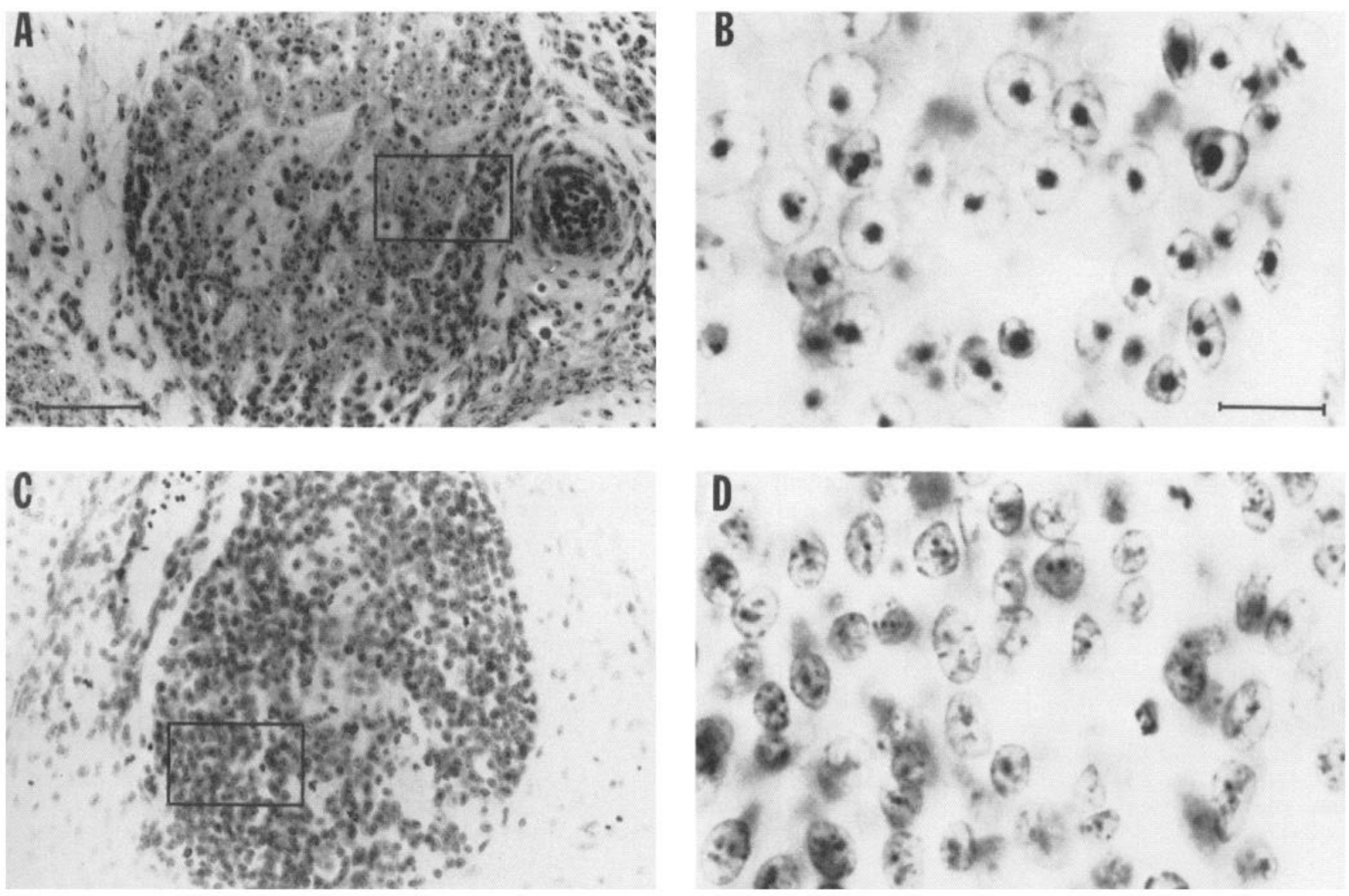

Figure 1. Example of quail $(A)$ and chick $(C) 15$ th cervical sympathetic ganglia $(C 15)$ at $8 \mathrm{~d}$ of incubation. $B$ and $D$, High-power views of insets in $A$ and $C$, respectively, showing that the heterochromatin of quail cells is usually condensed, whereas that of the chick is dispersed. Using quail cells as a natural cell marker, the formation of sympathetic and dorsal root ganglia could be studied by following the migration of transplanted quail neural crest cells in chick hosts. Calibration bars, $50 \mu \mathrm{m}$ in $A, C ; 10 \mu \mathrm{m}$ in $B, D$.

\section{Histological preparation}

Embryos were fixed with Carnoy solution, cleared with amyl acetate, and embedded in paraffin (Hamburger et al., 1981). Serial transverse sections were cut at $10 \mu \mathrm{m}$ and stained by the Feulgen-Rossenbeck reaction (Feulgen and Rossenbeck, 1924).

\section{Histological examination}

For each embryo, the sympathetic chain, the dorsal root ganglia, and spinal cord along the rostrocaudal axis were reconstructed from serial transverse sections. The brachial plexus (which is formed by the convergence of the $\mathrm{C} 13-\mathrm{C} 16$ spinal nerves) and the lateral motor column (which extends from the $\mathrm{C} 13$ to $\mathrm{Cl} 6$ spinal cord segments) were also reconstructed. The segmental levels of individual ganglia were then determined by using the brachial plexus and lateral motor column as landmarks (Hamburger et al., 1981). The exact segmental level of the transplant was also ascertained, in this case by identifying the spinal cord segment or segments that contained only quail cells.

For each of 18 experimental animals, the left and right sympathetic chains, as well as dorsal root ganglia, were examined throughout their extent for the presence of quail cells (see Fig. 1). (Only 35 cases were examined because 1 side of 1 experimental animal was damaged during processing.) In 5 stage 37-38 (11-12 d) embryos in which extensive pigmentation of feathers had occurred because of the seeding of the epidermis by quail melanocytes the rostrocaudal limits of the skin showing quail-like (pigmented) feathers were identified from serial transverse sections. In 4 cases where the transplant was restricted to a single spinal segment, the spatial distribution of quail cells along the sympathetic chain ganglia was determined in a more detailed way, together with the number of quail cells in each ganglion. This latter value is expressed as a percentage of the total number of quail cells distributed along the entire sympathetic chain.

\section{Results}

\section{Migration of sympathetic ganglioblasts along the rostrocaudal} axis

Sympathetic ganglion cells originating from transplants of quail neural primordium 1-2 segments long were found in several contiguous paravertebral ganglia of the chick host (see Fig. 5). In all cases $(N=35)$, ganglion cells of quail origin were found in at least 3 contiguous ganglia (Fig. 3). With the exception of 2 cases, quail cells migrated $1-3$ segments rostrally and $1-5$ segments caudally. In the remaining 2 cases, one showed no rostral migration and the other showed no caudal migration of quail cells. On average, quail neural crest cells arising from transplants of neural primordium $1.4 \pm 0.08$ (SEM) segments in length migrated $1.9 \pm 0.14$ segments rostrally and $2.8 \pm 0.17$ segments caudally to populate the sympathetic chain of the chick host. No significant difference was found in this behavior between 1 and 2 segment transplants $\left(\mathrm{T}_{33}=1.57 ; p>0.05\right)$. Nor was a difference found in the extent of sympathetic ganglioblast migration in embryos operated between stages 11 and 15 (40$55 \mathrm{hr}$ ) (Fig. 4). Thus, at least within the confines of these stages, there does not appear to be any temporal factor that determines how many ganglia are populated by a given segment of the neural crest. Furthermore, no difference in the extent of sympathetic ganglioblast migration was found in embryos sacrificed between stages 33 and $38(71 / 2-12 \mathrm{~d})$. Accordingly, the migration of sympathetic ganglioblasts appears to be complete before stage 33 $(71 / 2 d)$. 


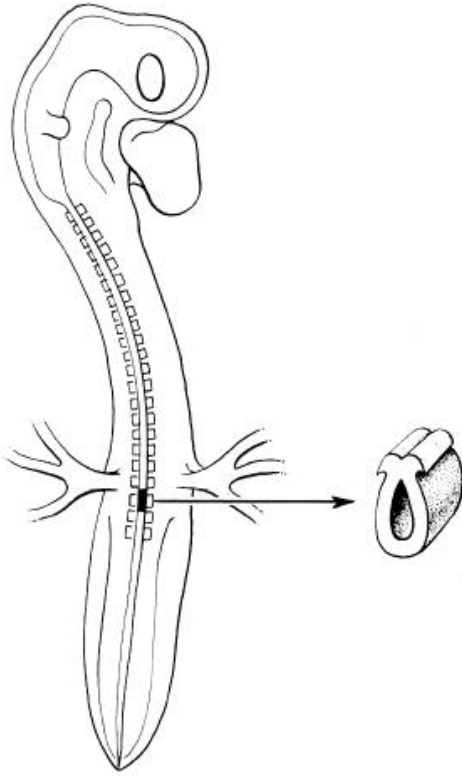

Quail

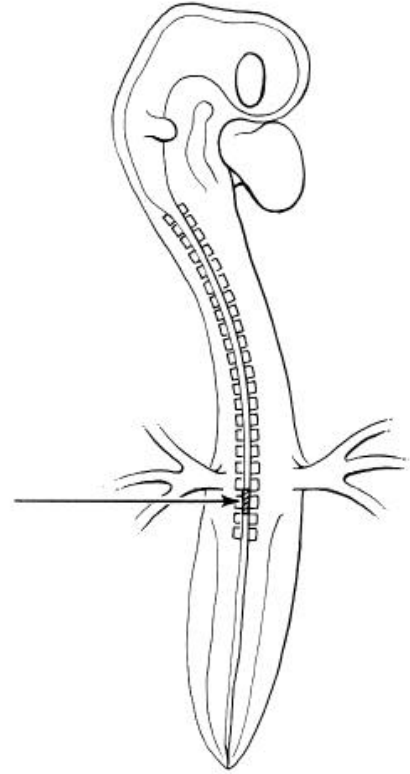

Chick

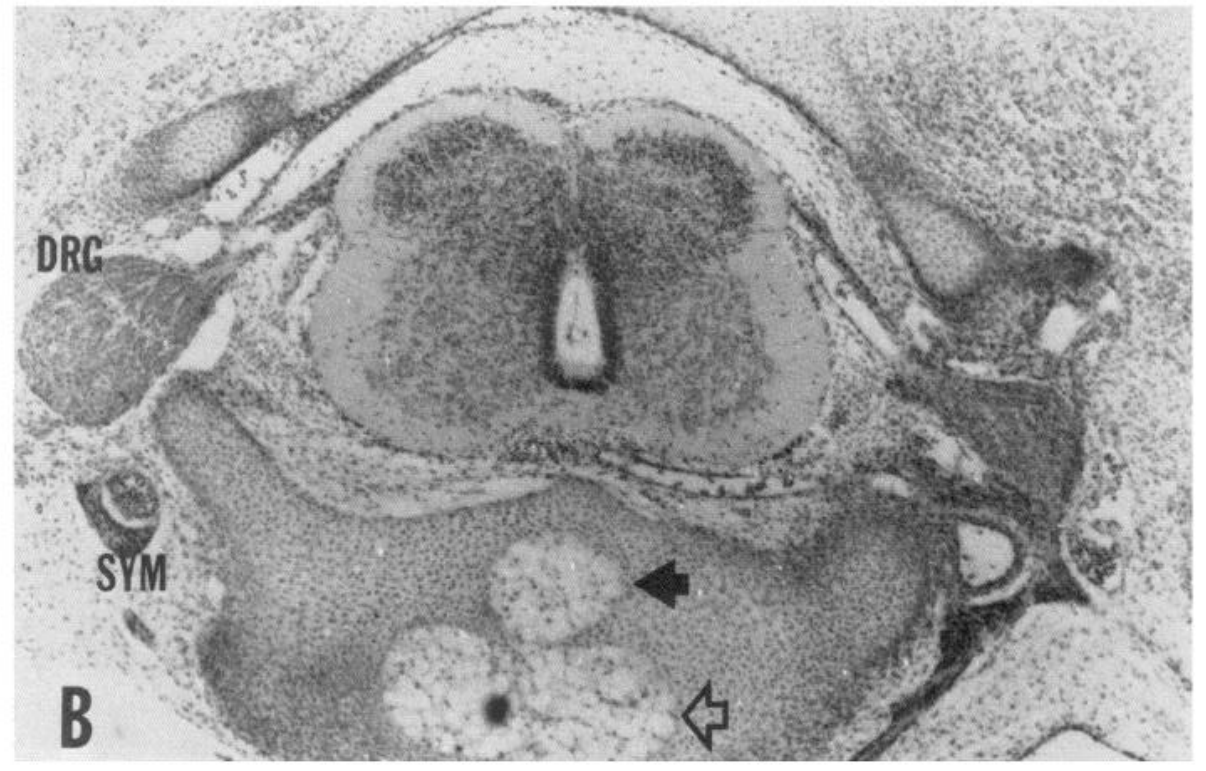

Figure 2. A, Transplantation of neural primordium from a quail donor into a chick host. A piece of neural primordium 1-2 cord segments in length was removed from lower cervical or upper thoracic segments of a quail donor at stages $11-15(40-55 \mathrm{hr})$ and transplanted into a chick host of a similar stage. The transplant was placed at the same segmental level after removing the corresponding segment(s) from the host. $B$, Transplanted region of a stage $33(71 / 2-8 \mathrm{~d})$ chick embryo that had received a homotopic transplantation of 1-2 segments of quail neural primordium $5 \mathrm{~d}$ earlier. The spinal cord, the paired dorsal root ganglia $(D R G)$, and sympathetic ganglia $(S Y M)$ all appeared to have formed normally. There are, however, two notochords in this embryo, one derived from the quail (solid arrow) and the other from the chick (open arrow).
In summary, sympathetic ganglioblasts originating from transplants of 1 or 2 segments of neural crest at cervical or thoracic levels migrated along the rostrocaudal axis to populate multiple ganglia of the sympathetic chain.

Rostrocaudal distribution of sympathetic ganglion cells originating from transplanted neural primordium

Sympathetic ganglion cells originating from a single segment of the transplanted neural primordium are distributed in a graded manner in a number of contiguous ganglia both rostral and caudal to the transplant region (Figs. 5, 6). Thirty-nine percent of the sympathetic ganglion cells originating from the quail neural primordium were found in the ganglia adjacent to the transplant $(N=4)$. The percentage of quail cells diminished as a function of distance in more rostral and caudal ganglia. The segmental distribution of quail cells along the sympathetic chain ganglia also revealed a tendency of sympathetic ganglioblasts to migrate further caudally than rostrally. First, quail cells were 


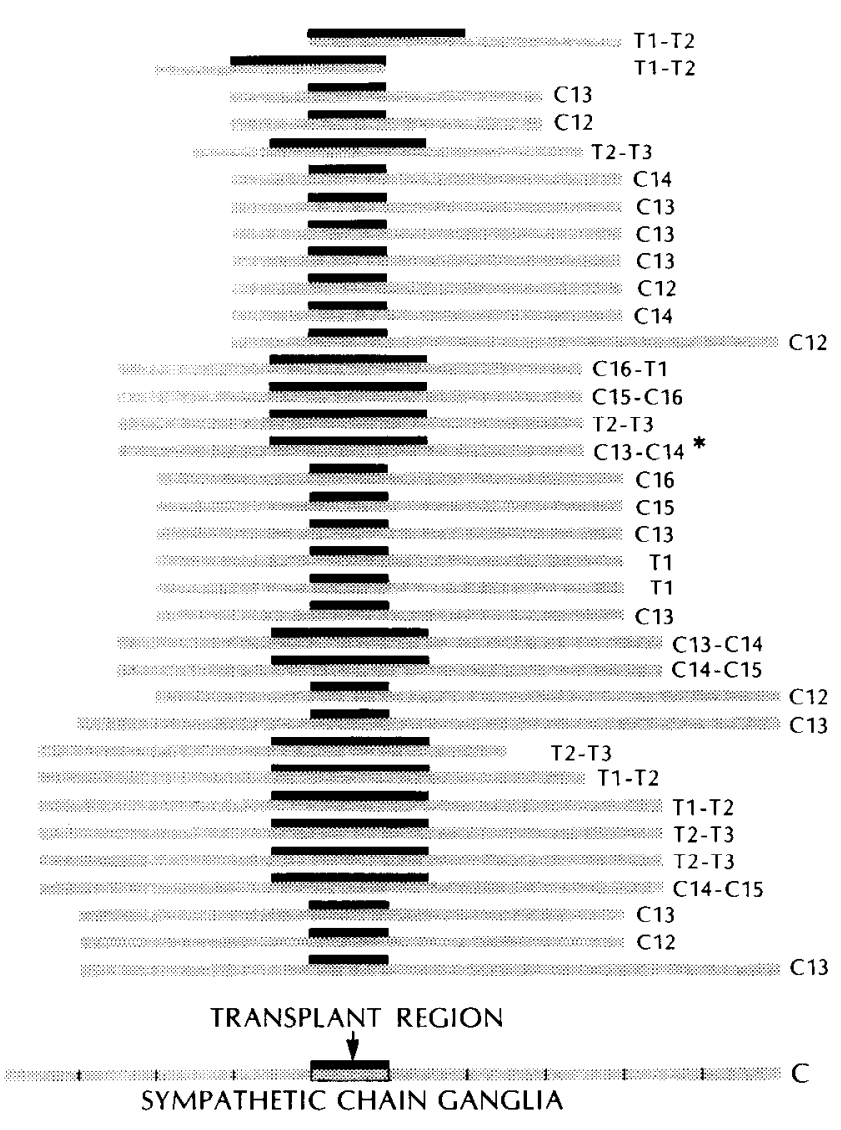

Figure 3. Rostrocaudal migration of sympathetic ganglion cells originating from transplanted neural primordium. The presence of quail cells in ganglia of both the left and right sympathetic chains was examined in 18 chimeric embryos 5-10 d after transplantation. Each stippled bar represents the distribution of quail cells along the sympathetic chain. The 1-2 segment transplant, identified by cord segments that contained only quail cells, is represented in each case by a black $b a r$. All the animals are aligned at the transplant region, even though the level of transplantation varied (as indicated by numbers at right). In every case, quail cells were found in sympathetic ganglia 1-3 segments rostral and $1-5$ segments caudal to the transplant region. On average, quail cells arising from 1-2 segments of the transplanted neural primordium were found in 6 contiguous sympathetic ganglia.

found in more ganglia caudal than rostral to the transplant region (Fig. 3). In addition, more quail cells were found in each ganglion caudal to the transplant region than the corresponding rostral ganglia (Figs. 5, 6). Finally, in ganglia where many quail and chick cells were found, quail cells were randomly distributed among the chick cells (Fig. 6, $A-D$ ). In the most distant ganglia, where quail cells were few in number, the heterotypic cells were sometimes found in clusters in only a small region of the ganglia (Fig. 6, E, F).

\section{Migration of dorsal root ganglioblasts}

The presence of quail cells was also examined in dorsal root ganglia of all experimental embryos. In every case, quail cells were confined to the dorsal root ganglia adjacent to the transplant (Fig. 7, $A, B$ ). Dorsal root ganglia rostral and caudal to the transplant region were completely devoid of quail cells (Fig. $7, C-F)$. However, a few host (chick) cells were sometimes found in the dorsal root ganglia adjacent to the transplant.

The simplest explanation given these findings is that dorsal root ganglion cells arise from the neural crest of the corresponding segment. Moreover, the results suggest that the migration of dorsal root ganglioblasts is a relatively early event. Thus, by

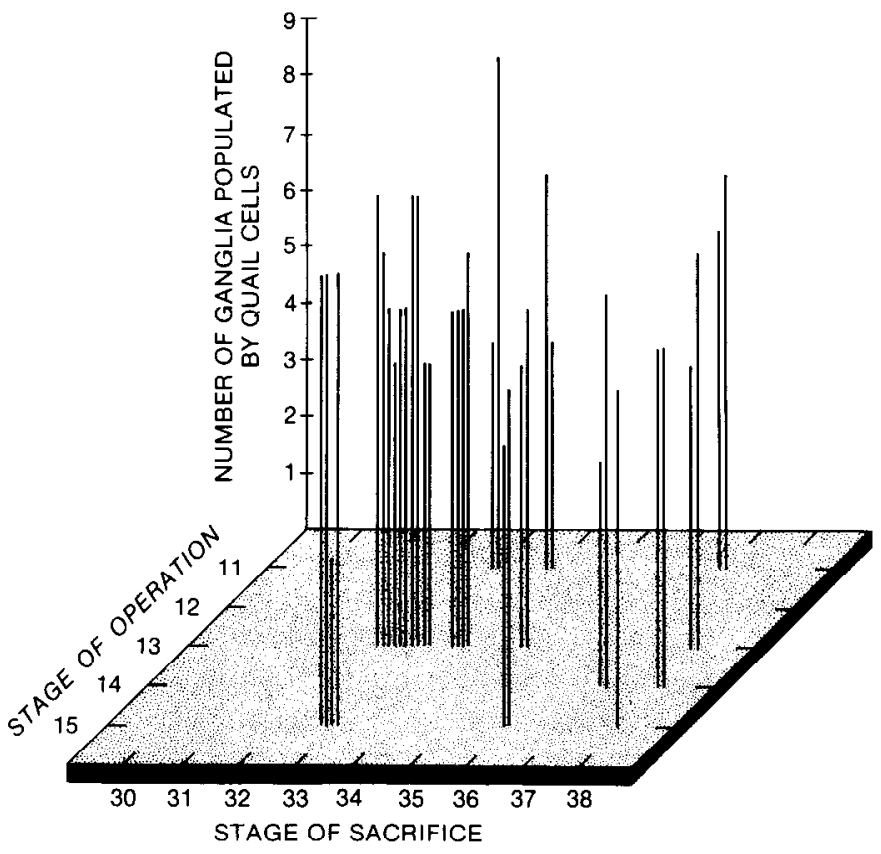

Figure 4. Extent of quail cell migration in chimeras created and sacrificed at various stages. Each vertical line shows the number of ganglia in a single sympathetic chain populated by quail cells arising from the transplanted neural primordium. The position of each vertical line in the horizontal plane indicates the stage at which the transplantation was performed and the stage at which the embryo was sacrificed. The extent of neural crest migration was similar whether the transplant was performed at stage $11(40-45 \mathrm{hr}$ ) or stage $15(50-55 \mathrm{hr})$. The extent of neural crest migration was also similar whether embryos were sacrificed at stage $33(71 / 2-8 \mathrm{~d})$ or stage $38(12 \mathrm{~d})$.

stages 11-15 (40-50 hr), when the transplantations of neural primordia were performed, some dorsal root ganglioblasts have already migrated away from the hosts' neural crest, resulting in the appearance of host cells in the dorsal root ganglia at the level of the transplant.

\section{Migration of melanocytes}

As in the case of sympathetic ganglion cells, melanocytes originating from single segments of the neural crest populated relatively large areas of the chick host. Transplantation at the T1 level, for instance, resulted in pigmentation of the chick host between the lower neck and the thigh (Fig. 8). Serial reconstructions of the rostrocaudal extent of pigmented feathers in 5 stage 37-38 (11-12 d) chick hosts indicated that melanocytes arising from 1 or 2 segments of neural primordium populated 11-14 segments of skin. On average they migrated $4.6 \pm 0.6$ (SEM) segments rostrally and $6.6 \pm 0.5$ segments caudally. Thus, the segments populated by melanocytes arising from the transplant overlapped with, but extended beyond those populated by sympathetic ganglioblasts. As in the case of sympathetic ganglioblasts, there was a tendency for melanocytes arising from lower cervical and upper thoracic levels to migrate preferentially in the caudal rather than in the rostral direction (see also Teillet, 1971).

\section{Discussion}

My results indicate that precursors of sympathetic ganglion cells and melanocytes of the trunk region are capable of considerable rostrocaudal migration. Moreover, precursors of melanocytes that arise from a local region of the neural crest migrate farther along the rostrocaudal axis than do precursors of sympathetic ganglion cells. In general, there is a tendency for these neural 
crest derivatives to migrate further in the caudal than in the rostral direction. Precursors of dorsal root ganglion cells, in contrast, do not migrate along the rostrocaudal axis; instead, they migrate ventromedially to give rise to the dorsal root ganglia of the same segmental level.

These differences in the migratory behavior of different neural crest derivatives indicate that the rostrocaudal migration of sympathetic ganglion cells, as well as melanocytes, is not simply an anomalous effect of transplantation per se. Instead, the difference in the pattern of migration among different neural crest derivatives is likely to be a result of their local environment. Indeed, when neural crest cells are transplanted from the vagal to the trunk region or vice versa, they adopt the migratory pathways that are characteristic of cells of the new location (LeDouarin, 1980; LeDouarin and Teillet, 1973; see also Noden, 1975). Focal changes in the composition of the extracellular matrix through which neural crest cells migrate have been associated with the migration and aggregation of neural crest cells. Neural crest migration has been observed to proceed along pathways that are rich in fibronectin; on the other hand, migration ceases with the appearance of nerve cell adhesion molecule (N-CAM) and the concomitant focal disappearance of fibronectin (Rovasio et al., 1983; Rutishauser et al., 1978; Thiery et al., 1982).

An obvious difference in the migratory behavior of dorsal root and sympathetic ganglion cells is the absence of rostrocaudal movement of dorsal root ganglion cells. A possible explanation for this finding is that dorsal root ganglion cells cannot migrate through the sclerotome, which thus forms a physical barrier for the rostrocaudal migration of these neurons (see Thiery et al., 1982). In support of this view is the recent finding that migrating neural crest cells, labeled with the monoclonal antibody $\mathrm{NCl}$, were never found within the sclerotome (Vincent and Thiery, 1984). In addition, the segmental arrangement of dorsal root ganglia has been found to depend on the presence of the segmentally arranged somites, which gives rise to the sclerotome (Detwiler, 1934; see also Weston, 1963). The progenitors of dorsal root ganglion cells, as suggested by Thiery and his collaborators (Thiery et al., 1982; Vincent and Thiery, 1984), appear to be the neural crest cells that face the bulk of the somite. Thus, the rostrocaudal migration of these cells, as well as their ventral migration to the paranotochordal region, is prevented by the sclerotome. The reason for the difference in the extent of rostrocaudal migration between precursors of melanocytes and sympathetic ganglion cells is not clear; again, however, it is likely to be found in the structure of the environment through which the neural crest cells migrate. Precursors of melanocytes migrate dorsolaterally in the mesenchyme between the ectoderm and the dermomytome (Teillet, 1971; see, however, Weston, 1963), whereas precursors of sympathetic ganglion cells appear to migrate ventromedially in the intcrsomitic space to form first the primary sympathetic trunk dorsolateral to the aorta before migrating dorsally towards the ventral roots to form the definitive secondary sympathetic trunk (Kirby and Gilmore, 1976; Vincent and Thiery, 1984). Concurrent with the dorsal migration of sympathetic ganglioblasts to form the secondary sympathetic trunk is the outgrowth of preganglionic axons (Hollyday, 1985; Yip, 1985). The presence of preganglionic axons may also alter the migratory behavior of sympathetic ganglion cells.

Although the migration of sympathetic ganglion cell precursors along the rostrocaudal axis has been implicated in studies on the normal dispersion of neural crest cells (Vincent and Thiery, 1984) and in experimental studies where segments of neural crest were ablated (Yntema and Hammond, 1945), my results indicate, for the first time, the limits of their dispersion. Since, on average, sympathetic ganglioblasts originating from 1 or 2 segments of the lower cervical or upper thoracic neural crest migrate 2 segments rostrally and 3 segments caudally, individual

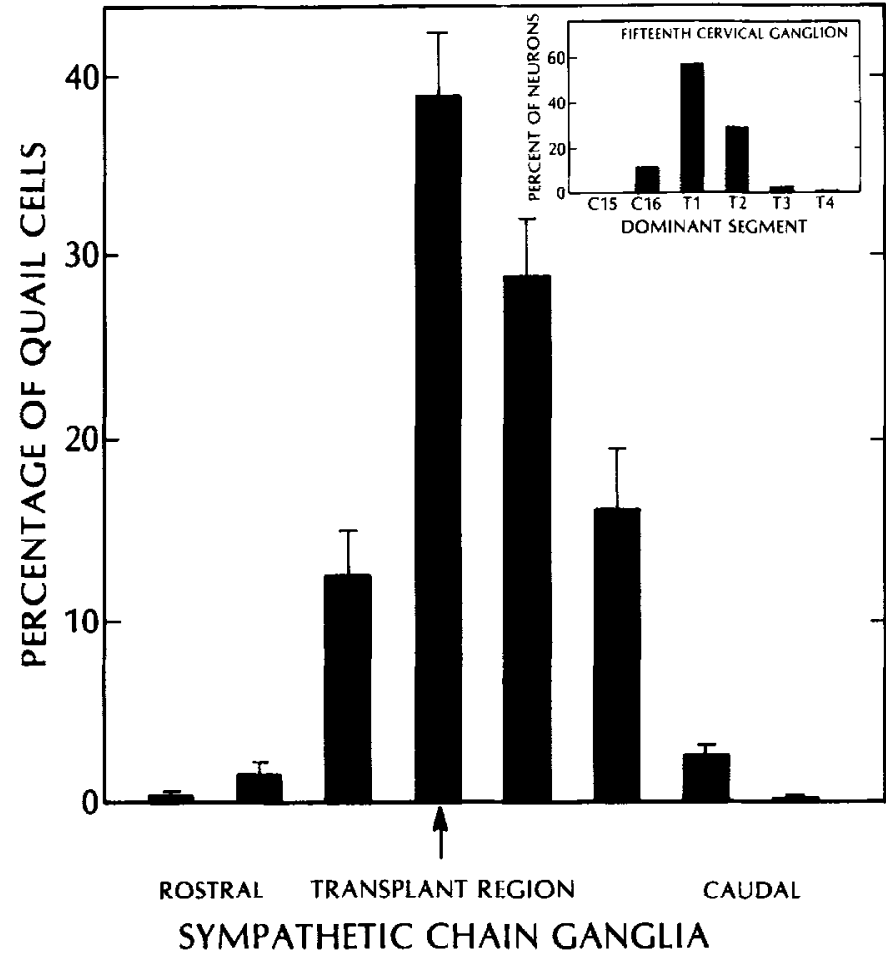

Figure 5. Segmental distribution of quail sympathetic ganglion cells originating from transplants of single segments of neural primordium. As in Figure 3, individual cases were aligned at the transplant region $(N=4)$. The number of quail cells found in ganglia rostral and caudal to the transplant region diminished as a function of distance from the transplant region. Inset, Percentage of neurons in the 15 th cervical ganglion that was dominated by preganglionic axons arising from different spinal cord segments (redrawn from Yip, 1986). The existence of several subpopulations of ganglion cells each dominated by preganglionic axons arising from a particular spinal cord segment appears to be a general feature of the sympathetic system (Yip, 1986) and has led to the idea that pre- and postganglionic neurons make preferential connections with one another based on their segmental origins in the neuraxis.

ganglia at these levels consist of cells that arise from about 6 spinal segments of the neural crest. The fact that the rostrocaudal extent of sympathetic ganglioblast migration is the same throughout stages $33-38(71 / 2-12 \mathrm{~d})$, a period that spans the peak of naturally occurring cell death (Oppenheim et al., 1982), indicates that cell death does not play a significant role in shaping the final pattern of sympathetic ganglioblast migration.

Of special interest is the similarity between the number of neural crest segments contributing to each sympathetic ganglion and the number of spinal cord segments contributing to its innervation (Fig. 5). Thus, as reported in the accompanying paper (Yip, 1986), each ganglion in the chick is innervated by preganglionic axons arising from 6 spinal cord segments. The innervation of individual neurons in these ganglia is segmentally specific, with each cell being innervated by only some of the spinal segments that supply each ganglion as a whole. This subset of spinal segments is always contiguous, with 1 segment providing the dominant innervation to the cell; spinal segments adjacent to the dominant segment provide synaptic inputs whose strength diminishes as a function of distance from the dominant segment.

A similar pattern of ganglion cell innervation has been demonstrated in the sympathetic ganglion of several different mammals (Lichtman and Purves, 1980; Njâ and Purves, 1977a; Rubin, 1985). The systematically graded innervation of individual ganglion cells by different spinal cord segments is presumably the cellular basis for the activation of sympathetic end-organs 

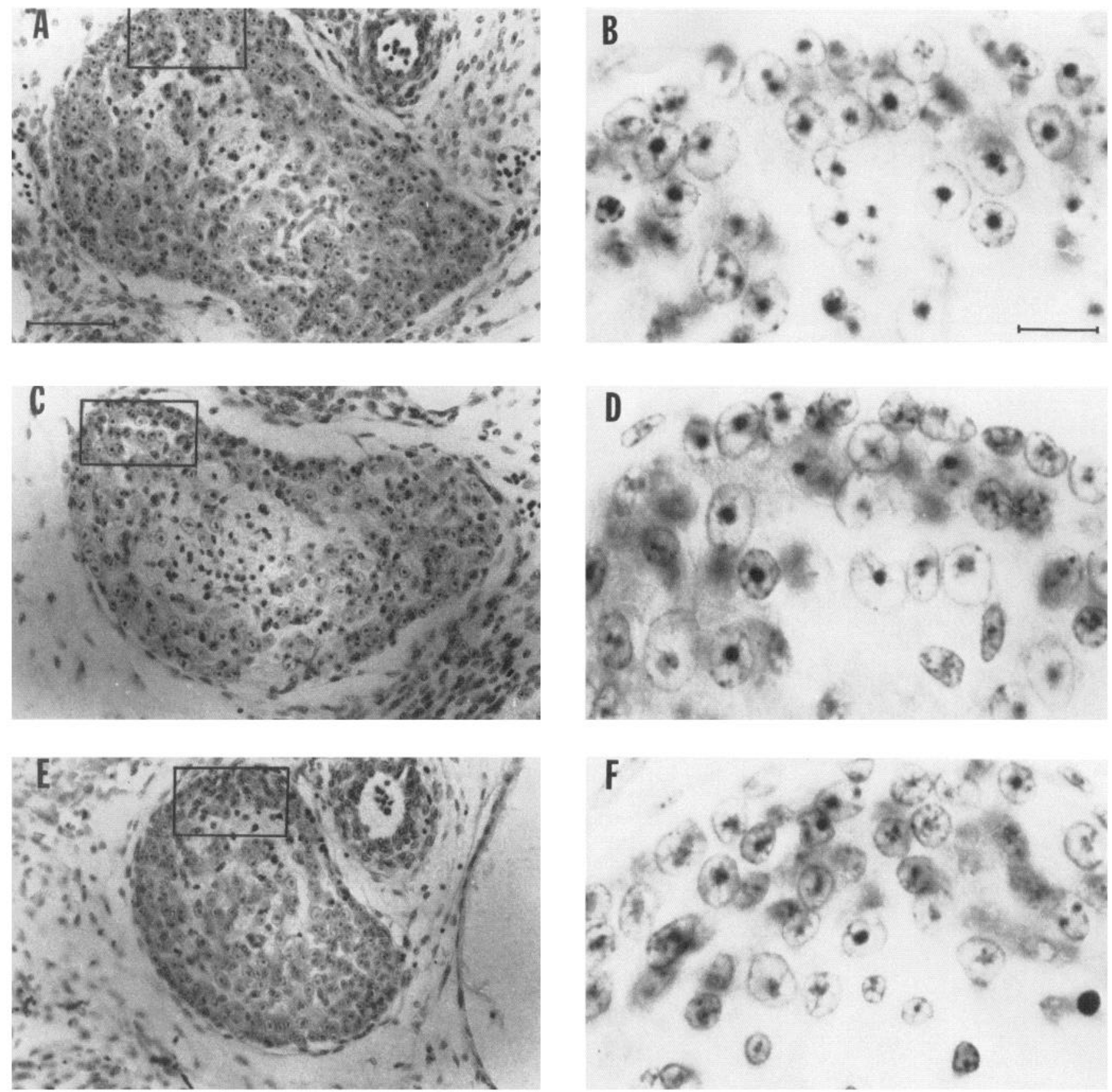

Figure 6. Rostrocaudal distribution of sympathetic ganglion cells originating from transplants of quail neural primordium. $A$, Sympathetic ganglion at the level of the transplant. The majority of quail cells were found at this level. $C$, Sympathetic ganglion 2 segments caudal to the region of the transplant. In this ganglion, many fewer quail cells were found, where they were distributed apparently at random among chick cells. $E$, Sympathetic ganglion 2 segments rostral to the region of the transplant. The number of quail cells is substantially reduced; in the micrograph shown here, only a few cells are evident (inset). In general, there were fewer quail cells in ganglia rostral to the transplant region. $B, D$, and $F$, High-power views of insets in $A, C$, and $E$, respectively. The overall segmental distribution of cells from this animal is indicated by the asterisk in Figure 3 . Calibration bars, $50 \mu \mathrm{m}$ in $A, C, E ; 10 \mu \mathrm{m}$ in $B, D, F$.

at different regions of the body (Lichtman et al., 1979). Furthermore, upon transection of the cervical sympathetic trunk and re-innervation of the superior cervical ganglion in the guinea pig, the stereotyped pattern of ganglion cell innervation and the characteristic end-organ responses are restored, indicating that ganglion cells have been selectively re-innervated by preganglionic axons (Njå and Purves, 1977b, 1978). The similarity in the innervation of avian and mammalian sympathetic neurons suggests that the innervation of avian sympathetic neurons by preganglionic axons is also selective. In both instances, the re- lationship between pre- and postganglionic cells appears to be positional; ganglion cells that innervate a particular peripheral target area are innervated predominantly by preganglionic axons arising from the same spinal cord segment (Lichtman et al., 1979; Rubin and Purves, 1980; see also Purves et al., 1981).

How positional attributes of pre- and postsynaptic neurons are translated into a basis for selective synapse formation is not known. By analogy with other systems in which the early positions of pre- and postsynaptic neurons appear to be important for their subsequent interactions, it is possible that selective 

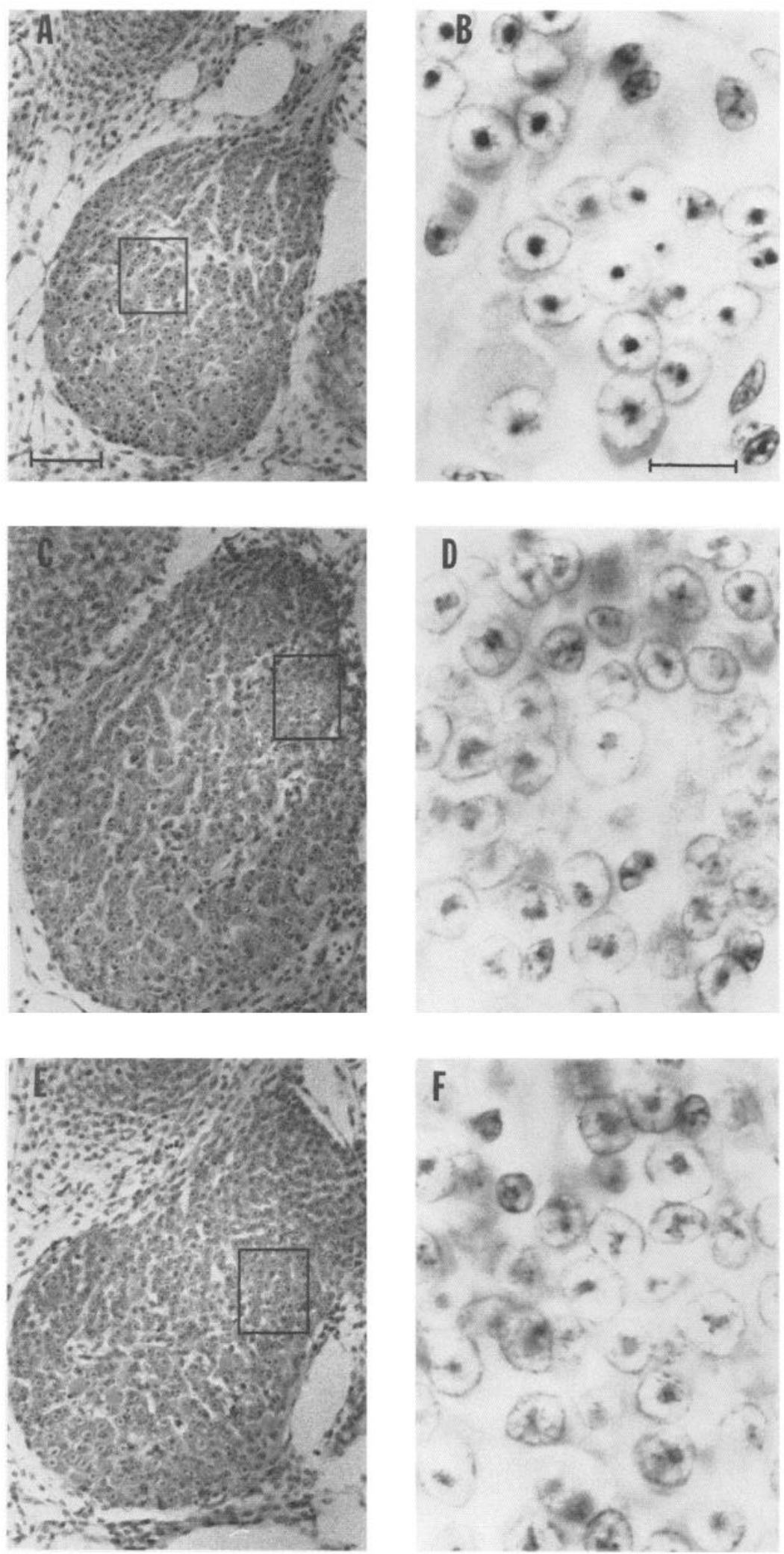

Figure 7. Dorsal root ganglia at various rostrocaudal levels of the transplant. $A$, Dorsal root ganglion at the level of the transplant. $C$ and $E$, Dorsal root ganglia 1 segment rostral $(C)$ and caudal $(E)$ to the region of the transplant. $B, D$, and $F$, High-power insets of $A, C$, and $E$, respectively. The ganglion cells at the level of the transplant are almost entirely of quail origin. Adjacent ganglia were nearly devoid of quail cells. This indicates that dorsal root ganglion cells originate almost exclusively from neural crest cells of the corresponding segment. The formation of the dorsal root ganglion from the neural crest is therefore different than that of the sympathetic ganglion, where the constituent neurons originate from multiple segments of the neural crest. Calibration bars, $50 \mu \mathrm{m}$ in $A, C, E ; 10$ $\mu \mathrm{m}$ in $B, D, F$.

synaptogenesis in this system is based on surface labels that are acquired as a result of the segmental origins of pre- and postganglionic neurons along the neuraxis (see Rubin and Purves, 1980). The similarity between the number of neural crest segments contributing to each sympathetic ganglion and the number of spinal cord segments contributing to its innervation adds further weight to the possibility that pre- and postganglionic neurons are matched according to their segmental origins along the neuraxis.

Matching between pre- and postganglionic neurons originating from the same position in the neuraxis might simply be based on the acquisition of a similar positional label. This mech- 


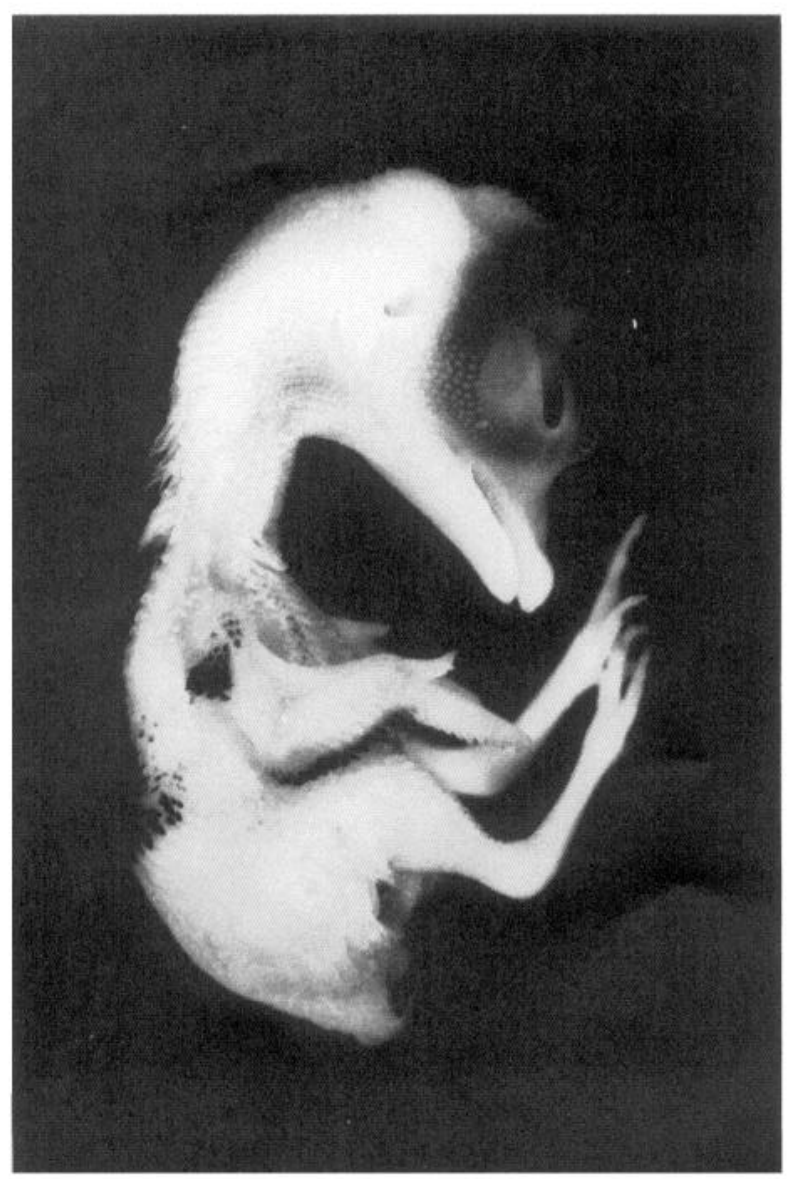

Figure 8. Stage 37 (11 d) chick embryo that had received a homotopic transplantation of 1-2 segments of quail neural primordium in the upper thoracic region $81 / 2 \mathrm{~d}$ earlier. Melanocytes, which arise from the neural crest of the quail donor, have populated the feather tracts throughout the brachial and thoracic levels of the chick host.

anism might operate in mammals, for which there is some evidence that neurons of the superior cervical ganglion originate from the thoracic neural crest (Rubin, 1985). The matching of pre- and postganglionic neurons simply on the basis of a common origin, however, is not tenable in the cervical sympathetic ganglia of the chick. Whereas cervical sympathetic ganglion cells originate from local levels of the neural crest (see also LeDouarin, 1982; Newgreen, 1979; Thiery et al., 1982), their synaptic inputs are derived largely from preganglionic neurons that arise from thoracic levels of the spinal cord. Hence in this instance (and perhaps throughout the sympathetic systems), relative positional cues may be used to match pre- and postganglionic neurons during synapse formation. The demonstration that mammalian sympathetic ganglion cells or muscle fibers obtained from different segmental levels are selectively re-innervated by subpopulations of preganglionic axons of the cervical sympathetic trunk, with tissues obtained from more caudal spinal levels being re-innervated by preganglionic axons arising from relatively more caudal levels of the spinal cord (Purves et al., 1981; Wigston and Sanes, 1985), is consistent with this idea. Selective synaptic connections based on the positional attributes of pre- and postsynaptic neurons may indeed be a widespread phenomenon in the nervous systems of higher vertebrates.

\section{References}

Detwiler, S. R. (1934) An experimental study of spinal nerve segmentation in amblystoma with reference to the plurisegmental contri- bution to the brachial plexus. J. Exp. Zool. 67: 395-441.

Duband, J. L., and J. P. Thiery (1982) Distribution of fibronectin in the early phase of avian cephalic neural crest cell migration. Dev. Biol. 93: 24-39.

Feulgen, R., and H. Rossenbeck (1924) Mikroskopischchemischer Nachweis einer Nucleinsaure vom Typus der Thymonucleinaure und die darauf beruhende elektive. Farbung von Zellkernen in mikroskopischen Präparaten. Hoppe Seylers Z. Physiol. Chem. 135: 203252.

Hamburger, V., and H. L. Hamilton (1951) A series of normal stages in the development of the chick embryo. J. Morphol. 88: 49-92.

Hamburger, V., J. K. Brunso-Bechtold, and J. W. Yip (1981) Neuronal death in the spinal ganglia of the chick embryo and its reduction by nerve growth factor. J. Neurosci. 1: 60-71.

Hollyday, M. (1985) Light microscopic analysis of migration of sympathetic preganglionic neurons in chick embryos. Soc. Neurosci. Abstr. 11: 586 .

Kirby, M. L., and S. A. Gilmore (1976) A correlative histofluorescence and light microscopic study of the formation of the sympathetic trunks in chick embryos. Anat. Rec. 186: 437-450.

LeDouarin, N. (1969) Particularités du noyau interphasique chez la caille japonaise (Coturnix coturnix japonica). Utilisation de ces particularités comme 'marquage biologique' dans les recherches sur les interactions tissulaires et les migrations cellulaires au cours de l'ontogenèse. Bull. Biol. Fr. Belg. 103: 435-452.

LeDouarin, N. (1971) Caractéristiques ultrastructurales du noyau interphasique chez la caille et chez le poulet et utilisation de cellules de caille comme 'marqueurs biologiques' en embryologie expérimentale. Ann. Embryol. Morphog. 4: 125-135.

LeDouarin, N. (1973) A biological cell labelling technique and its use in experimental embryology. Dev. Biol. 30: 217-222.

LeDouarin, N. (1980) The ontogeny of the neural crest in avian embryo chimeras. Nature 286: 663-669.

LeDouarin, N. (1982) The Neural Crest, Cambridge U. P., Cambridge, UK.

LeDouarin, N. M., and M.-A. Teillet (1973) The migration of neural crest cells to the wall of the digestive tract in avian embryo. J. Embryol. Exp. Morphol. 30: 31-48.

LeDouarin, N. M., and M.-A. Teillet (1974) Experimental analysis of the migration and differentiation of neuroblasts of the autonomic nervous system and of neurectodermal mesenchymal derivatives, using a biological cell marking technique. Dev. Biol. 41: 162-184.

Levi-Montalcini, R. (1950) The origin and development of the visceral system in the spinal cord of the chick embryo. J. Morphol. 81: 253282.

Lichtman, J. W., and D. Purves (1980) The elimination of redundant preganglionic innervation to hamster sympathetic ganglion cells in early postnatal life. J. Physiol. (Lond.) 301: 213-228.

Lichtman, J. W., D. Purves, and J. W. Yip (1979) On the purpose of selective innervation of guinea-pig superior cervical ganglion cells. J. Physiol. (Lond.) 292: 69-84.

Newgreen, D. F. (1979) The rostral level of origin of sympathetic neurons in the chick embryo studied in tissue culture. Am. J. Anat. 154: $557-562$.

Newgreen, D. F., and J. P. Thiery (1980) The source and distribution of fibronectin in early avian embryos at the time of neural crest migration. Cell Tissue Res. 211: 269-292.

Njå, A., and D. Purves (1977a) Specific innervation of guinea-pig superior cervical ganglion cells by preganglionic fibres arising from different levels of the spinal cord. J. Physiol. (Lond.) 264: 565-583.

Njå, A., and D. Purves (1977b) Re-innervation of guinea-pig superior cervical ganglion cells by preganglionic fibres arising from different levels of the spinal cord. J. Physiol. (Lond.) 273: 633-651.

Njå, A., and D. Purves (1978) Specificity of initial synaptic contacts on guinea-pig superior cervical ganglion cells during regeneration of the cervical sympathetic trunk. J. Physiol. (Lond.) 281: 45-62.

Noden, D. M. (1975) An analysis of the migratory behavior of avian cephalic neural crest cells. Dev. Biol. 42: 106-130.

Oppenheim, R. W., J. L. Maderdrut, and D. J. Wells (1982) Cell death of motoneurons in the chick embryo spinal cord. VI. Reduction of naturally occurring cell death in the thoracolumbar column of Terni by nerve growth factor. J. Comp. Neurol. 210: 174-189.

Purves, D., W. Thompson, and J. W. Yip (1981) Re-innervation of ganglia transplanted to the neck from different levels of the guineapig sympathetic chain. J. Physiol. (Lond.) 313: 49-63. 
Rovasio, R. A., A. Delouvee, K. M. Yamada, R. Timpl, and J. P. Thiery (1983) Neural crest migration: Requirement for exogenous fibronectin and high cell density. J. Cell Biol. 96: 462-473.

Rubin, E. (1985) Development of the rat superior cervical ganglion: Ganglion cell maturation. J. Neurosci. 5: 673-684.

Rubin, E., and D. Purves (1980) Segmental organization of sympathetic preganglionic neurons in the mammalian spinal cord. J. Comp. Neurol. 192: 163-174.

Rutishauser, U., J. P. Thiery, R. Brackenbury, and G. M. Edelman (1978) Adhesion among neural cells of the chick embryo. III. Relationship of the surface molecule CAM to cell adhesion and the development of histotypic patterns. J. Cell Biol. 79: 371-381.

Teillet, M.-A. (1971) Recherches sur le mode de migration et la différenciation des mélanocytes cutanés chez l'embryon d'oiseau: étude expérimentale par la méthode des greffes hétérospécifiques entre embryons de caille et de poulet. Ann. Embryol. Morphog. 4: 95-109.

Thiery, J. P., J. L. Duband, and A. Delouvee (1982) Pathways and mechanisms of avian trunk neural crest cell migration and localization. Dev. Biol. 93: 324-343.
Tosney, K. W. (1978) The early migration of neural crest cells in the trunk region of the avian embryo: An electron microscopic study. Dev. Biol. 62: 317-333.

Vincent, M., and J. Thiery (1984) A cell surface marker for neural crest and placodal cells: Further evolution in peripheral and central nervous system. Dev. Biol. 103: 468-481.

Weston, J. A. (1963) A radioautographic analysis of the migration and localization of trunk neural crest cells in the chick. Dev. Biol. 6: 279310.

Wigston, D. J., and Sanes, J. R. (1985) Selective reinnervation of intercostal muscles transplanted from different segmental levels to a common site. J. Neurosci. 5: 1208-1221.

Yip, J. W. (1985) Projection patterns of sympathetic preganglionic axons in chick embryos. Soc. Neurosci. Abstr. 11: 64.

Yip, J. W. (1986) Specific innervation of neurons in the paravertebral sympathetic ganglia of the chick. J. Neurosci. 6: 3459-3464.

Yntema, C. L., and W. S. Hammond (1945) Depletions and abnormalities in the cervical sympathetic system of the chick following extirpation of the neural crest. J. Exp. Zool. 100: 237-263. 